\title{
Catalytic, Tunable, One-Step Bismuth(III) Triflate Reaction with Alcohols: Dehydration Versus Dimerization
}

\author{
Laura E. Kolsi, ${ }^{\dagger}$ Jari Yli-Kauhaluoma, ${ }^{\dagger}$ and Vânia M. Moreira* ${ }^{\dagger}, \ddagger(0)$
}

${ }^{\dagger}$ Drug Research Program, Division of Pharmaceutical Chemistry and Technology, Faculty of Pharmacy, University of Helsinki, Viikinkaari 5 E, P.O. Box 56, FI-00014 Helsinki, Finland

${ }^{\ddagger}$ Strathclyde Institute of Pharmacy and Biomedical Sciences, University of Strathclyde, 161 Cathedral Street, Glasgow G4 0RE, U.K.

Supporting Information

ABSTRACT: $\mathrm{Bi}(\mathrm{OTf})_{3} \cdot x \mathrm{H}_{2} \mathrm{O}$ is a powerful catalyst for the dehydration of tertiary alcohols into alkenes in apolar solvents. The reaction proceeds smoothly and selectively, with amounts as low as $0.01 \mathrm{~mol} \%$ catalyst, in yields up to $93 \%$. Moreover, in polar solvents, $\mathrm{Bi}(\mathrm{OTf})_{3} \cdot x \mathrm{H}_{2} \mathrm{O}(0.1-1 \mathrm{~mol} \%)$ selectively catalyzes the dimerization of the alcohols instead, forming new $\mathrm{C}-\mathrm{C}$ bonds, in yields up to $96 \%$. This mild, efficient, economic, and eco-friendly method is applicable across different chemical classes and amenable to several functional groups.
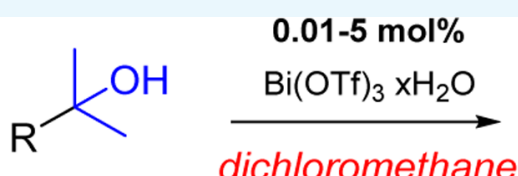<smiles>[R]C(=C)C</smiles>

dichloromethane

up to $93 \%$ yield

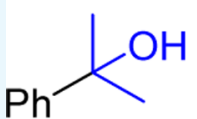

0.1-1 $\mathrm{mol} \%$

$\stackrel{\mathrm{Bi}(\mathrm{OTf})_{3} \mathrm{xH}_{2} \mathrm{O}}{\longrightarrow}$

nitromethane<smiles>C=C(CC(C)(C)P)c1ccccc1</smiles>

up to $96 \%$ yield

\section{INTRODUCTION}

The dehydration of alcohols into the corresponding alkenes is a widely used reaction in organic syntheses. ${ }^{1}$ Moreover, alkenes produced from alcohols largely present in biomass are critical raw materials for the production of plastics, fibers, and polymeric products. ${ }^{2,3}$ The dehydration of alcohols into alkenes is typically made using acid catalysis at elevated temperatures. ${ }^{1,3}$ However, these reaction conditions promote side reactions, including cyclization and rearrangement of the starting materials, and are far from ideal for compounds bearing labile chemical groups. Therefore, the pursuit of selective methods to dehydrate alcohols, through mild, costeffective, and efficient catalysis, remains a subject of interest for organic chemists. ${ }^{4}$

Bismuth(III) salts are versatile reagents for a variety of organic reactions, ${ }^{5}$ including syntheses of pharmaceutically interesting compounds as well as natural products. ${ }^{6}$ In addition to their broad reactivity, these compounds are relatively nontoxic and easy to handle, and therefore bismuth(III)-based chemistry is viewed as eco-friendly. Within bismuth(III) salts, $\mathrm{Bi}(\mathrm{OTf})_{3} \cdot x \mathrm{H}_{2} \mathrm{O}$ is appealing because it is commercially available, inexpensive, potentially reusable, and chemically versatile, as it can promote either Lewis or Brønsted acid catalysis. $^{5 \mathrm{~h}, 7}$

Bismuth(III) halides react with alcohols when used in stoichiometric amounts, in carbon tetrachloride, at reflux. ${ }^{8}$ $\mathrm{BiCl}_{3}$ halogenates all alcohol types other than primary, with dehydration as a side reaction, to give alkenes in low yields. Under the same conditions, $\mathrm{BiBr}_{3}$ dehydrates secondary and tertiary alcohols to the corresponding alkenes, but its reaction with benzylic alcohols gives ethers as the main product. Alkenes are also obtained from the reaction of secondary and tertiary alcohols with $\mathrm{Ph}_{3} \mathrm{BiBr}_{2} / \mathrm{I}_{2}$ in cyclohexane. ${ }^{9}$ However, under these conditions, some reactions are plagued by competing iodination. Altogether, these results suggest that $\mathrm{Bi}(\mathrm{OTf})_{3} \cdot x \mathrm{H}_{2} \mathrm{O}$ may be a suitable reagent for the dehydration of alcohols. Nonetheless, to the best of our knowledge, no study has yet addressed this question.

As a part of our ongoing work toward the semisynthesis of diterpenoids scarcely available from their natural sources, ${ }^{10}$ we recently became interested in suitable methods to build a 13propenyl side chain onto the diterpenic alcohol 1 . This modification is common to antiochic acid, ${ }^{11}$ diterpenoids from Pinus massoniana, ${ }^{12}$ aquilarabietic acid $\mathrm{H}$ from Chinese eaglewood, ${ }^{13}$ and bodinieric acids $\mathrm{C}$ and $\mathrm{F}$ from Callicarpa bodinieri, $^{14}$ some bearing relevant bioactivities. However, literature searches revealed that the methods available require halogenated reagents, nongreen solvents, or metals in strong acidic solutions, which are difficult to integrate in total syntheses campaigns. ${ }^{15-17}$ Therefore, we first studied the reactivity of $\mathrm{Bi}(\mathrm{OTf})_{3} \cdot x \mathrm{H}_{2} \mathrm{O}$ toward alcohol dehydration using $\mathbf{1}$ as a starting material.

\section{RESULTS AND DISCUSSION}

In the presence of $5 \mathrm{~mol} \% \mathrm{Bi}(\mathrm{OTf})_{3} \cdot x \mathrm{H}_{2} \mathrm{O}$, in refluxing chloroform, 1 was successfully converted into 2 , after $2 \mathrm{~h}$ and in $63 \%$ yield, after chromatographic purification (Table 1, entry 1). Similar results were observed with $1 \mathrm{~mol} \%$ of $\mathrm{Bi}(\mathrm{OTf})_{3} \cdot x \mathrm{H}_{2} \mathrm{O}$ (entry 2 ) and the overall amount of salt could be lowered to $0.1 \mathrm{~mol} \%$, with a gain in yield and extension of

Received: June 22, 2018

Accepted: July 24, 2018

Published: August 9, 2018 
Table 1. Catalytic Bi(OTf $)_{3} \cdot x \mathrm{H}_{2} \mathrm{O}$-Mediated Dehydration of 1

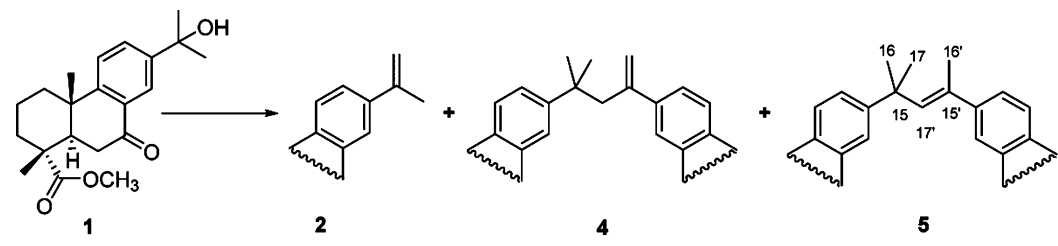

\begin{tabular}{|c|c|c|c|c|c|c|c|c|}
\hline \multirow[b]{2}{*}{ entry $^{a}$} & \multirow[b]{2}{*}{ Cat. (mol \%) } & \multirow[b]{2}{*}{ solvent } & \multirow[b]{2}{*}{ time $(\mathrm{h})$} & \multicolumn{5}{|c|}{ product $^{b}$} \\
\hline & & & & 2 & 3 & 4 & 5 & 1 \\
\hline 1 & 5 & $\mathrm{CHCl}_{3}$ & 2 & 63 & 9 & 0 & 0 & 0 \\
\hline 2 & 1 & $\mathrm{CHCl}_{3}$ & 2 & 74 & 6 & 0 & 0 & 0 \\
\hline 3 & 0.1 & $\mathrm{CHCl}_{3}$ & 24 & 85 & 4 & 0 & 0 & 0 \\
\hline 4 & 0.1 & $\mathrm{CH}_{2} \mathrm{Cl}_{2}$ & 2 & 88 & 0 & traces & 0 & 0 \\
\hline $5^{c}$ & 0.1 & $\mathrm{CH}_{2} \mathrm{Cl}_{2}$ & 24 & 84 & 0 & traces & 0 & 6 \\
\hline 6 & 0.1 & $\mathrm{EtOH}^{d}$ & 24 & 0 & 0 & 0 & 0 & 100 \\
\hline 7 & 1 & $\mathrm{EtOH}^{d}$ & 24 & 4 & 55 & 0 & 0 & 45 \\
\hline 8 & 5 & $\mathrm{EtOH}^{d}$ & 24 & 23 & 52 & 0 & 0 & 0 \\
\hline 9 & 10 & $\mathrm{EtOH}^{d}$ & 24 & 7 & 73 & 0 & 0 & 0 \\
\hline 10 & 20 & $\mathrm{EtOH}^{d}$ & 2 & 8 & 74 & 0 & 0 & 0 \\
\hline 11 & 10 & $\mathrm{EtOH}$ & 24 & 0 & 0 & $38^{e}$ & $43^{e}$ & 0 \\
\hline 12 & 0.1 & 1,4-dioxane $\mathrm{e}^{d}$ & 4 & 0 & 0 & 0 & 0 & 100 \\
\hline 13 & 1 & 1,4-dioxane $e^{d}$ & 2 & 74 & 0 & 0 & 0 & 0 \\
\hline 14 & 1 & THF & 24 & 90 & 0 & 0 & 0 & 0 \\
\hline 15 & 1 & $\mathrm{CH}_{3} \mathrm{CN}$ & 2 & 47 & 0 & 57 & traces & 0 \\
\hline 16 & 10 & $\mathrm{CH}_{3} \mathrm{CN}$ & 2 & 11 & 0 & $55^{e}$ & $23^{e}$ & 0 \\
\hline 17 & 0.1 & $\mathrm{CH}_{3} \mathrm{NO}_{2}$ & 24 & 23 & 0 & 11 & 0 & 67 \\
\hline 18 & 1 & $\mathrm{CH}_{3} \mathrm{NO}_{2}$ & 2 & 18 & 0 & 71 & 0 & 0 \\
\hline
\end{tabular}

${ }^{a}$ General experimental conditions: compound 1 ( $\left.0.050 \mathrm{~g}, 0.15 \mathrm{mmol}\right)$, solvent $(1.8 \mathrm{~mL})$, and reflux. ${ }^{b}$ Yield after purification by flash column chromatography (FCC). ${ }^{c}$ Reaction made at room temperature. ${ }^{d}$ Dry solvent. ${ }^{e}$ Yield calculated from the ${ }^{1} \mathrm{H}$ NMR spectra.

the reaction time (entry 3 ). However, under these reaction conditions, formation of 3 as a side product, with an ethoxy group at position 15 occurred (Scheme 1), most likely because of the presence of ethanol used as a stabilizer for chloroform.

\section{Scheme 1. Proposed Reaction Mechanism}

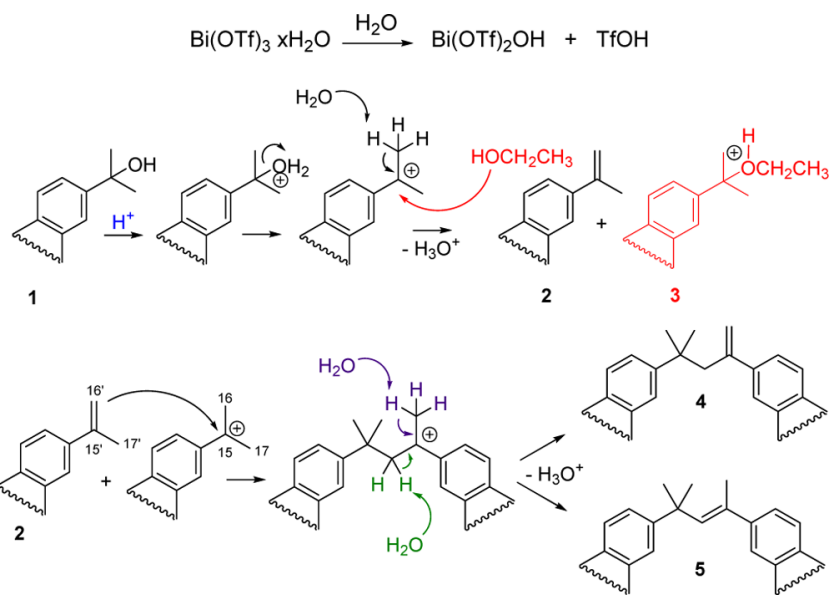

To rule out this effect, we next screened the reaction in dichloromethane (Table 1, entries 4-5) and in ethanol (entries 6-11). Indeed, in dichloromethane, the reaction proceeded with $0.1 \mathrm{~mol} \%$ of $\mathrm{Bi}(\mathrm{OTf})_{3} \cdot x \mathrm{H}_{2} \mathrm{O}$, at reflux or room temperature, without formation of 3 , and alkene 2 was isolated, in $84-88 \%$ yield. The reaction was slower at room temperature and a small amount of 1 remained unmodified. In addition, traces of a side product which we later identified as dimeric compound 4 was formed (entries $4-5)$. No reactivity was observed in dry ethanol with $0.1 \mathrm{~mol} \%$ of $\mathrm{Bi}(\mathrm{OTf})_{3} \cdot x \mathrm{H}_{2} \mathrm{O}$ (entry 6) and when the amount of salt was increased to $20 \mathrm{~mol}$ $\%$ increasing the amounts of $\mathbf{3}$ formed as expected (entries 710). However, in nondry ethanol (entry 11), a major change in the reactivity occurred. Compound 3 did not form and a mixture of the two dimeric compounds 4 and $5^{a}$ was instead obtained. This result pointed to the dramatic effect of water in the reaction outcome.

The results in dry 1,4-dioxane (entries 12-13) corroborated this finding and further revealed that solvent polarity is another crucial parameter toward the reaction outcome. Thus, there was no reactivity with $0.1 \mathrm{~mol} \%$ of $\mathrm{Bi}(\mathrm{OTf})_{3} \cdot x \mathrm{H}_{2} \mathrm{O}$ in dry solvent, at reflux, whereas $74 \%$ of 2 was isolated as the single reaction product, using $1 \mathrm{~mol} \%$ of salt, under the same conditions. In the absence of water, $\mathbf{4}$ and $\mathbf{5}$ did not form, and in nonpolar solvents such as 1,4-dioxane and dichloromethane, the formation of the alkene derivative $\mathbf{2}$ was favored. A very high yield of $\mathbf{2}$ was also obtained in a relatively nonpolar tetrahydrofuran (THF) (entry 14), even if nondry. In polar, nondry solvents such as acetonitrile or nitromethane (entries 15-18), in a similar fashion to ethanol (entry 11), 4 and 5 became the major reaction products. The use of $1 \mathrm{~mol} \%$ of $\mathrm{Bi}(\mathrm{OTf})_{3} \cdot x \mathrm{H}_{2} \mathrm{O}$ in refluxing nitromethane was ideal for the preparation of 4 .

The findings in Table 1 suggest a Brønsted acid behavior for $\mathrm{Bi}(\mathrm{OTf})_{3} \cdot x \mathrm{H}_{2} \mathrm{O}$ as opposed to Lewis acid, in the reaction mechanism, that is, triflic acid is produced in situ from $\mathrm{Bi}(\mathrm{OTf})_{3} \cdot x \mathrm{H}_{2} \mathrm{O}$, which then drives the reaction forward (Scheme 1). To gain further evidence of Brønsted acidmediated catalysis, 1 was reacted with $\mathrm{Bi}(\mathrm{OTf})_{3} \cdot x \mathrm{H}_{2} \mathrm{O}(1 \mathrm{~mol}$ 
$\%)$, in dichloromethane, at reflux, in the presence of 2,6-di-tbutylpyridine $(10 \mathrm{~mol} \%),{ }^{18}$ a proton scavenger that is unable to coordinate to metal ions because of the bulky $t$-butyl groups. No reactivity was observed, indicating the need for protons in the reaction medium to promote it, according to Scheme 1 . In addition, when the reaction was made using triflic acid $(10 \mathrm{~mol}$ $\%$ ), full conversion of $\mathbf{1}$ into 2,4 , and 5 occurred in 58, 25, and $6 \%$ yields, respectively, in $2 \mathrm{~h}$.

We also investigated whether $\mathrm{Bi}(\mathrm{OTf})_{3} \cdot x \mathrm{H}_{2} \mathrm{O}$ could promote the direct homodimerization of 2 based on a previous study on the heterodimerization of vinylarenes where indium triflate was a Lewis acid catalyst. ${ }^{19}$ However, we found that this was not the case as in refluxing 1,4-dioxane, with $5 \mathrm{~mol} \%$ of $\mathrm{Bi}(\mathrm{OTf})_{3} \cdot x \mathrm{H}_{2} \mathrm{O}$, no reactivity was observed and with $10 \mathrm{~mol}$ $\%$, formation of a mixture of dimers 4 and 5 occurred, without exhaustion of the starting material. Exploration of other solvents including a 3:1 mixture of THF and cyclohexane ${ }^{20}$ in the presence of $10 \mathrm{~mol} \%$ of $\mathrm{Bi}(\mathrm{OTf})_{3} \cdot x \mathrm{H}_{2} \mathrm{O}$ resulted in no reactivity, even after $24 \mathrm{~h}$, at reflux. Nitromethane was the best solvent for this modification; however, $5 \mathrm{~mol} \%$ of $\mathrm{Bi}(\mathrm{OTf})_{3}$. $x \mathrm{H}_{2} \mathrm{O}$ was required, and several products were formed among which the mixture of dimers $\mathbf{4}$ and $\mathbf{5}$ was the major.

Overall, the results suggest that alkene 2 is formed by protonation of the hydroxy group at position $\mathrm{C} 13$ of 1 , which forms a good leaving group and a very stable tertiary carbocation (Scheme 1). Compound 3 forms in chloroform only because of the presence of ethanol which acts as a nucleophile. Dimers $\mathbf{4}$ and $\mathbf{5}$ form after electrophilic addition of the carbocation to the double bond of 2 . A new tertiary carbocation forms which is converted into 4 and 5 in the presence of water. In nondry solvents, water originates most likely from $\mathrm{Bi}(\mathrm{OTf})_{3} \cdot x \mathrm{H}_{2} \mathrm{O}$ which is hygroscopic. Of note, the formation of $\mathbf{4}$ and $\mathbf{5}$ is in line with previous reports describing the dimerization of styrene catalyzed by acids ${ }^{21}$ as well as via proton transfer to carbonyl compounds. ${ }^{22}$ The "super acid" triflimide was also reported to promote the hydroalkenylation of vinylarenes. ${ }^{20}$ In all cases, the formation of a benzylic cation which suffers attack by vinylarenes through nucleophilic addition, followed by deprotonation to form the dimeric product, is proposed as the reaction mechanism.

Different metal salts were next screened for comparison with $\mathrm{Bi}(\mathrm{OTf})_{3} \cdot x \mathrm{H}_{2} \mathrm{O}$. The results are depicted on Table 2, showing that none of the tested salts was better for the synthesis of 2 from 1 .

We further investigated the scope of the reaction using other diterpenic benzylic alcohols (6-9), bearing different functional groups (Scheme 2). We extended the set to accommodate the nonbenzylic sesquiterpenic tertiary alcohol cedrol 14, the nonterpenic benzylic alcohol 16, a nonbenzylic tertiary alcohol 19, and the steroidal secondary alcohol $5 \alpha$-cholestan- $3 \beta$-ol 22. The reaction was successful in all diterpenic alcohols tested, although there was a need to increase the amounts of catalyst used to exhaust the starting materials, most likely because of the presence of atoms which coordinate with $\mathrm{Bi}(\mathrm{OTf})_{3} \cdot x \mathrm{H}_{2} \mathrm{O}$ and somewhat diminish its catalytic power. Nonetheless, compounds 10-13 were all successfully prepared and isolated in yields ranging from 63 to $83 \%$, after chromatographic purification. The reaction was also successful for the dehydration of cedrol 14 into cedrene 15, in 91\% yield.

Notably, alcohol 16 gave the alkene 17 and the dimer 18, with $94.6 \%$ conversion, in an $83: 17$ ratio, with as little as 0.01 mol \% of the catalyst. Moreover, alcohol 19 gave alkenes 20 and 21 in a ratio of $93: 7$, with a $96.6 \%$ conversion, albeit with a
Table 2. Catalyst Screening for the Dehydration of 1

\begin{tabular}{|c|c|c|c|c|c|c|}
\hline \multirow[b]{2}{*}{ entry $^{a}$} & \multirow[b]{2}{*}{ Cat. (mol \%) } & \multirow[b]{2}{*}{ time $(\mathrm{h})$} & \multicolumn{4}{|c|}{ product $^{b}$} \\
\hline & & & 2 & 4 & 5 & 1 \\
\hline 1 & $\mathrm{BiCl}_{3}(5)$ & 24 & 50 & traces & 0 & 20 \\
\hline 2 & $\mathrm{BiCl}_{3}(10)$ & 24 & 58 & 17 & traces & 0 \\
\hline 3 & $\mathrm{BiBr}_{3}(10)$ & 24 & 44 & 35 & traces & 0 \\
\hline 4 & $\mathrm{Cu}(\mathrm{OTf})_{2}(5)$ & 24 & 63 & 0 & 0 & traces \\
\hline 5 & $\mathrm{Cu}(\mathrm{OTf})_{2}(7.5)$ & 24 & 71 & 0 & 0 & 0 \\
\hline 6 & $\mathrm{Sc}(\mathrm{OTf})_{3}(5)$ & 24 & 60 & 0 & 0 & 20 \\
\hline 7 & $\mathrm{Sc}(\mathrm{OTf})_{3}(15)$ & 24 & 67 & traces & 0 & 0 \\
\hline 8 & $\mathrm{Yb}(\mathrm{OTf})_{3}(20)$ & 24 & 23 & 0 & 0 & 60 \\
\hline 9 & $\mathrm{La}(\mathrm{OTf})_{3}(20)$ & 24 & 15 & 0 & 0 & 79 \\
\hline 10 & $\operatorname{In}(\mathrm{OTf})_{3}(10)$ & 2 & 84 & traces & 0 & 0 \\
\hline 11 & $\operatorname{In}(\mathrm{OTf})_{3}(20)$ & 2 & 47 & 25 & traces & 0 \\
\hline
\end{tabular}

${ }^{a}$ General experimental conditions: compound 1 ( $0.050 \mathrm{~g}, 0.15$ $\mathrm{mmol}), \mathrm{CH}_{2} \mathrm{Cl}_{2}(1.8 \mathrm{~mL})$, and reflux. ${ }^{b}$ Yield after purification by FCC.

\section{Scheme 2. Scope of the Reaction ${ }^{a}$}
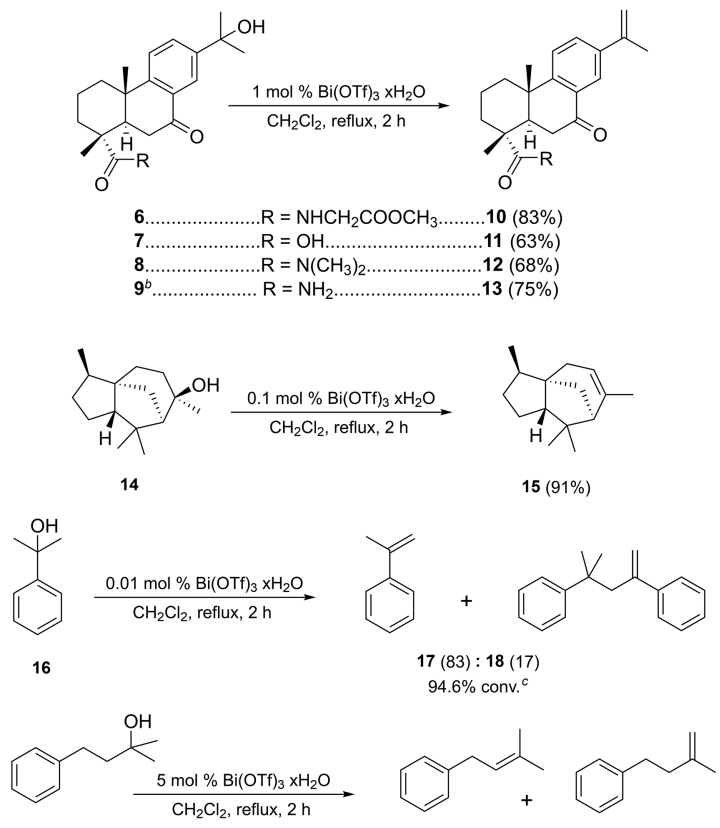

19

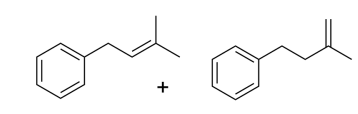

$20(93): 21(7)$ $96.6 \%$ conv. $^{\circ}$
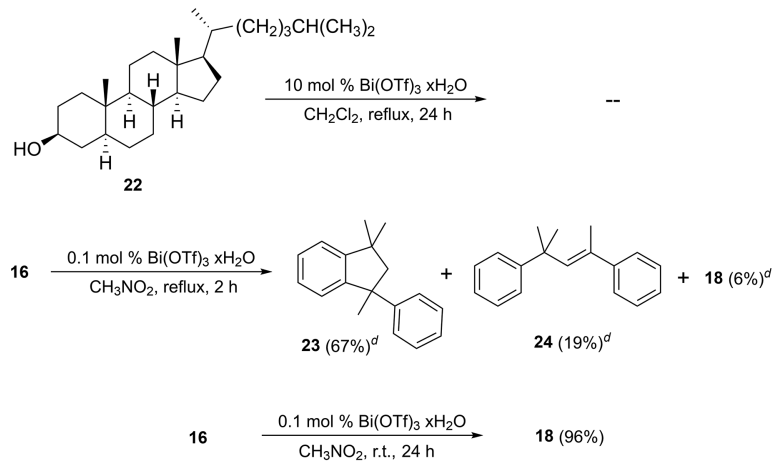

${ }^{a}$ Yield after purification by FCC. ${ }^{b} 5 \mathrm{~mol} \% \mathrm{Bi}(\mathrm{OTf})_{3} \cdot x \mathrm{H}_{2} \mathrm{O}$ was used. ${ }^{c}$ Determined by gas chromatography-mass spectrometry (GC-MS). ${ }^{d}$ Calculated from the ${ }^{1} \mathrm{H}$ NMR spectrum.

higher amount of catalyst, reflecting the lower reactivity of nonbenzylic alcohols toward this method. In line with this 
finding, the reaction was unsuccessful for the dehydration of 22. These results support the proposed reaction mechanism which proceeds via formation of a carbocation, and the observed reactivity reflects the stability of the participant carbocation formed in each case, that is, benzylic alcohols are the most reactive followed by tertiary alcohols, and secondary alcohols are unreactive.

In nitromethane, alcohol $\mathbf{1 6}$ gave the indane derivative $\mathbf{2 3}$ with an amount as low as $0.1 \mathrm{~mol} \%$ catalyst, in $67 \%$ yield, along with the dimeric products $\mathbf{2 4}$ and $\mathbf{1 8}$ as minor products (Scheme 2). This result is not entirely surprising because a previous study reports the preparation of 23 from 16 in the presence of stoichiometric amounts of $\mathrm{BiBr}_{3}$ in chloroform, after cyclization of 18, at high temperatures. ${ }^{23}$ In sharp contrast, using an amount as low as $0.1 \mathrm{~mol} \%$ of $\mathrm{Bi}(\mathrm{OTf})_{3}$. $x \mathrm{H}_{2} \mathrm{O}$ in nitromethane, we prepared the dimer 18 from the small alcohol 16, as the single reaction product, at room temperature, in $96 \%$ yield. Cyclization toward indane products was never observed with 1 most likely because of stereochemical impediment.

To illustrate the utility of our method, we used $\mathrm{Bi}(\mathrm{OTf})_{3}$. $x \mathrm{H}_{2} \mathrm{O}$ as an alcohol dehydrating agent for the unprecedented semisynthesis of diterpenoids from $P$. massoniana, ${ }^{12}$ starting from commercially available dehydroabietic acid $\mathbf{2 5}$ (Scheme 3 ). The alkene 2 was a key intermediate, and the desired product $27^{b}$ was synthesized over five steps.

Scheme 3. Semisynthesis of 13-Propenyl-7-hydroxyabieta8,11,13-trien-18-oic Acid 27

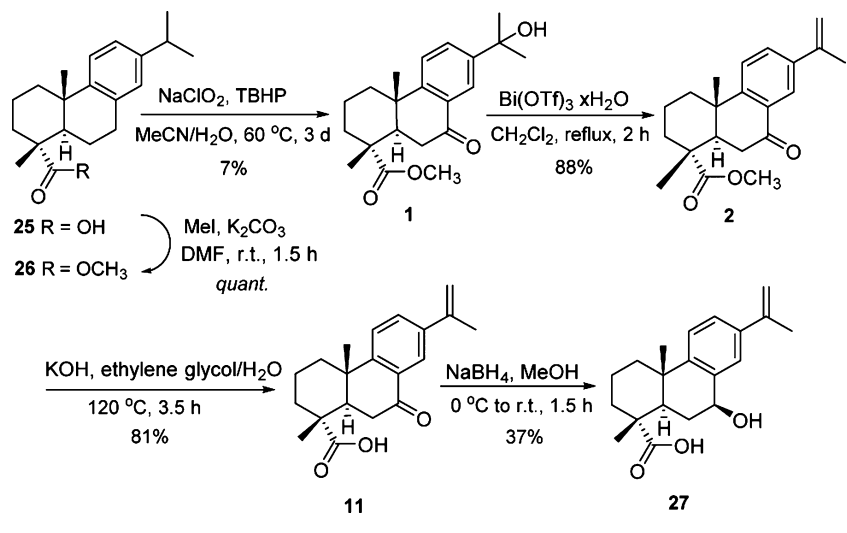

In conclusion, herein, we show that the reaction of $\mathrm{Bi}(\mathrm{OTf})_{3} \cdot x \mathrm{H}_{2} \mathrm{O}$ with tertiary alcohols is tunable toward obtaining either alkenes or dimers, in high yields and selectivity. This method employs an eco-friendly and relatively inexpensive catalyst, in very low loading, for accessing two different, novel and practical synthetic methodologies, under reaction conditions, amenable to a variety of functional groups. We believe this method is of general utility in the field of organic chemistry and can in addition be easily incorporated into total syntheses design.

\section{EXPERIMENTAL SECTION}

General Remarks. Dehydroabietic acid (90\% purity) was purchased from Pfaltz \& Bauer, USA, and other reagents were obtained from Sigma-Aldrich Co, VWR International Oy or Fluorochem Ltd. Silica gel 60 F254 was used for thin-layer chromatography. FCC was made with a Biotage HighPerformance Flash Chromatography Sp4-system (Uppsala,
Sweden). The apparatus has a $0.1 \mathrm{~mm}$ path length flow cell UV detector/recorder module (fixed wavelength: $254 \mathrm{~nm}$ ). SNAP cartridges of 10,25 , or $50 \mathrm{~g}$ were used in the purifications with a flow rate of $10-50 \mathrm{~mL} / \mathrm{min}$. A Vertex 70 (Bruker Optics Inc., MA, USA) FTIR instrument was used to collect the IR spectra, with a horizontal attenuated total reflectance (ATR) accessory (MIRacle, Pike Technology, Inc, WI, USA). Transmittance $\left(4000-600 \mathrm{~cm}^{-1}\right)$ was recorded at a $4 \mathrm{~cm}^{-1}$ resolution, and spectra were produced with the OPUS 5.5 (Bruker Optics Inc., MA, USA) software. For NMR analysis collected on a Bruker Ascend 400 spectrometer, in $\mathrm{CDCl}_{3}$ or $\mathrm{CD}_{3} \mathrm{OD}$ with tetramethylsilane (TMS) as the internal standard, chemical shifts are reported in parts per million (ppm) and on the $\delta$ scale from TMS. The coupling constant $J$ is quoted in hertz. A Waters UPLC-ESI/QTOF-MS using a Synapt G2 HDMS (Waters, MA, USA) instrument was used for the exact mass analysis. Purity was executed with Waters Acquity UPLC system (Waters, Milford MA, USA) attached to Acquity PDA detector and Waters Synapt G2 HDMS mass spectrometer (Waters, Milford MA, USA) via an ESI ion source. An Agilent 7890A GC system attached to Agilent 7000 GS/MS Triple Quad was used for the collection of GC-MS. The preparation and characterization of compounds 6,8 , and 9 have been previously reported. ${ }^{10}$ Compounds $3,4,10,11,12$, and $\mathbf{1 3}$ have not been previously reported and were obtained as amorphous solids.

General Procedure for the $\mathrm{Bi}(\mathrm{OTf})_{3} \cdot \mathrm{xH}_{2} \mathrm{O}$-Catalyzed Dehydration of Alcohols. To a stirred solution of the alcohol $(0.050 \mathrm{~g})$ in dichloromethane $(1.8 \mathrm{~mL}), \mathrm{Bi}(\mathrm{OTf})_{3}$. $x \mathrm{H}_{2} \mathrm{O}$ was added. The temperature was raised to reflux, and stirring was continued for $2 \mathrm{~h}$. The solvent was evaporated under vacuum, the residue was diluted with ethyl acetate (10 $\mathrm{mL})$, and water $(5 \mathrm{~mL})$ was added. The aqueous phase was extracted with ethyl acetate $(2 \times 10 \mathrm{~mL})$. The combined organic phases were washed with a saturated aqueous solution of $\mathrm{NaHCO}_{3}(10 \mathrm{~mL})$, water $(10 \mathrm{~mL})$, brine $(10 \mathrm{~mL})$, dried over anhydrous $\mathrm{Na}_{2} \mathrm{SO}_{4}$, and filtered. After removal of the solvent under reduced pressure, the resulting crude product was purified by flash chromatography on silica gel using ethyl acetate in $n$-hexane $(0 \rightarrow 100 \%)$ as the eluant.

Methyl 13-Propenyl-7-oxoabieta-8,11,13-trien-18-oate (2). White solid. ${ }^{1} \mathrm{H}$ NMR (400 $\left.\mathrm{MHz}, \mathrm{CDCl}_{3}\right): \delta 1.27$ (s, $3 \mathrm{H}), 1.34(\mathrm{~s}, 3 \mathrm{H}), 1.74(\mathrm{~m}, 5 \mathrm{H}), 2.15(\mathrm{~m}, 3 \mathrm{H}), 2.36(\mathrm{~m}, 2 \mathrm{H})$, $2.72(\mathrm{~m}, 2 \mathrm{H}), 3.65(\mathrm{~s}, 3 \mathrm{H}), 5.11(\mathrm{~m}, 1 \mathrm{H}), 5.41(\mathrm{~m}, 1 \mathrm{H}), 7.34$ $(\mathrm{d}, J=8.3 \mathrm{~Hz}, 1 \mathrm{H}), 7.65(\mathrm{dd}, J=8.3,2.2 \mathrm{~Hz}, 1 \mathrm{H}), 8.08(\mathrm{~d}, J=$ $2.2 \mathrm{~Hz}, 1 \mathrm{H}) .{ }^{13} \mathrm{C}$ NMR $\left(101 \mathrm{MHz}, \mathrm{CDCl}_{3}\right): \delta 16.5,18.3,21.8$, 23.8, 36.7, 37.2, 37.6, 38.0, 43.9, 46.8, 52.4, 113.2, 123.6, 124.4, $130.7,131.3,139.4,142.2,154.5,177.9,198.5$. IR (ATR): 2947, 2928, 1724, 1676, 1250,1124, 895, $841 \mathrm{~cm}^{-1}$. HRMS $m / z$ : calcd for $\mathrm{C}_{21} \mathrm{H}_{27} \mathrm{O}_{3}, 327.1961[\mathrm{M}+\mathrm{H}]^{+}$; found, 327.1960 .

Methyl 15-Ethoxy-7-oxoabieta-8,11,13-trien-18-oate (3). Pale semisolid. ${ }^{1} \mathrm{H}$ NMR $\left(400 \mathrm{MHz}, \mathrm{CDCl}_{3}\right): \delta 1.16(\mathrm{t}, J=7.0$ $\mathrm{Hz}, 3 \mathrm{H}), 1.27(\mathrm{~d}, J=0.8 \mathrm{~Hz}, 3 \mathrm{H}), 1.35(\mathrm{~s}, 3 \mathrm{H}), 1.53(\mathrm{~s}, 3 \mathrm{H})$, $1.54(\mathrm{~s}, 3 \mathrm{H}), 1.76(\mathrm{~m}, 5 \mathrm{H}), 2.36(\mathrm{~m}, 2 \mathrm{H}), 2.73(\mathrm{~m}, 2 \mathrm{H}), 3.20$ $(\mathrm{q}, J=7.0 \mathrm{~Hz}, 2 \mathrm{H}), 3.66(\mathrm{~s}, 3 \mathrm{H}), 7.36(\mathrm{~d}, J=8.3 \mathrm{~Hz}, 1 \mathrm{H}), 7.66$ (dd, $J=8.3,2.2 \mathrm{~Hz}, 1 \mathrm{H}), 7.98(\mathrm{~d}, J=2.2 \mathrm{~Hz}, 1 \mathrm{H}) .{ }^{13} \mathrm{C} \mathrm{NMR}$ $(101 \mathrm{MHz}, \mathrm{CDCl} 3): \delta 16.0,16.5,18.3,23.8,28.4,28.5,36.7$, 37.2 , 37.5, 38.0, 43.9, 46.9, 52.4, 58.3, 76.4, 123.7, 124.5, 130.6, 131.9, 145.3, 154.1, 178.0, 198.5. IR: 2978, 1726, 1682, 1236, 1069, 756 (ATR) $\mathrm{cm}^{-1}$. HRMS $\mathrm{m} / z$ : calcd for $\mathrm{C}_{23} \mathrm{H}_{33} \mathrm{O}_{4}$, 373.2379 $[\mathrm{M}+\mathrm{H}]^{+}$; found, 373.2380. 
Dimeric Compound (4). White solid. ${ }^{1} \mathrm{H}$ NMR (400 MHz, $\left.\mathrm{CDCl}_{3}\right): \delta 1.20(\mathrm{~m}, 3 \mathrm{H}), 1.23(\mathrm{~s}, 3 \mathrm{H}), 1.25(\mathrm{~d}, J=3.4 \mathrm{~Hz}$, $6 \mathrm{H}), 1.34(\mathrm{~d}, J=1.7 \mathrm{~Hz}, 6 \mathrm{H}), 1.70(\mathrm{~m}, 10 \mathrm{H}), 2.33(\mathrm{~m}, 4 \mathrm{H})$, $2.69(\mathrm{~m}, 4 \mathrm{H}), 2.84(\mathrm{~s}, 2 \mathrm{H}), 3.67(\mathrm{~s}, 3 \mathrm{H}), 3.67(\mathrm{~s}, 3 \mathrm{H}), 4.85(\mathrm{~d}$, $J=1.5 \mathrm{~Hz}, 1 \mathrm{H}), 5.18(\mathrm{~d}, J=1.5 \mathrm{~Hz}, 1 \mathrm{H}), 7.16(\mathrm{~m}, 2 \mathrm{H}), 7.33$ (dd, $J=8.2,2.2 \mathrm{~Hz}, 1 \mathrm{H}), 7.41(\mathrm{dd}, J=8.3,2.3 \mathrm{~Hz}, 1 \mathrm{H}), 7.88$ $(\mathrm{d}, J=2.1 \mathrm{~Hz}, 1 \mathrm{H}), 7.93(\mathrm{~d}, J=2.3 \mathrm{~Hz}, 1 \mathrm{H}) .{ }^{13} \mathrm{C} \mathrm{NMR}(101$ $\left.\mathrm{MHz}, \mathrm{CDCl}_{3}\right): \delta 16.5,18.3,23.9,23.9,28.9,36.6,36.6,37.1$, $37.3,37.5,38.0,38.0,38.6,43.9,44.0,46.8,49.1,52.4,52.4$, $118.1,123.0,123.3,124.8,125.2,130.2,130.5,132.3,132.3$, 141.4, 145.3, 147.4, 152.7, 154.0, 177.9, 178.0, 198.4, 198.6. IR (ATR): 2943, 1724, 1682, 1244, 1111, 833, $754 \mathrm{~cm}^{-1}$. HRMS $m / z$ : calcd for $\mathrm{C}_{42} \mathrm{H}_{53} \mathrm{O}_{6}, 653.3842[\mathrm{M}+\mathrm{H}]^{+}$; found, 653.3843 .

Methyl 15-Propenyl-7-oxo-N-(abieta-8,11,13-trien-18oyl)glycinate (10). Using the general procedure, compound 10 was prepared from 6. ${ }^{10}$ Compound 10: white solid. ${ }^{1} \mathrm{H}$ NMR (400 MHz, $\mathrm{CDCl}_{3}$ ): $\delta 1.27(\mathrm{~s}, 3 \mathrm{H}), 1.40(\mathrm{~s}, 3 \mathrm{H}), 1.68$ (m, $2 \mathrm{H}), 1.86(\mathrm{~m}, 3 \mathrm{H}), 2.15(\mathrm{~m}, 3 \mathrm{H}), 2.37(\mathrm{~m}, 1 \mathrm{H}), 2.46(\mathrm{~m}$, $1 \mathrm{H}), 2.69(\mathrm{~m}, 2 \mathrm{H}), 3.77(\mathrm{~s}, 3 \mathrm{H}), 4.03(\mathrm{dd}, J=5.0,1.7 \mathrm{~Hz}$, $2 \mathrm{H}), 5.10(\mathrm{~m}, 1 \mathrm{H}), 5.40(\mathrm{~m}, 1 \mathrm{H}), 6.32(\mathrm{~m}, 1 \mathrm{H}), 7.33(\mathrm{~d}, J=$ $8.3 \mathrm{~Hz}, 1 \mathrm{H}), 7.65(\mathrm{dd}, J=8.3,2.2 \mathrm{~Hz}, 1 \mathrm{H}), 8.05(\mathrm{~d}, J=2.2 \mathrm{~Hz}$, 1H). ${ }^{13} \mathrm{C}$ NMR $\left(101 \mathrm{MHz}, \mathrm{CDCl}_{3}\right): \delta 16.5,18.4,21.8,23.8$, 36.9 , 37.1, 37.4, 37.6, 41.8, 44.0, 46.6, 52.6, 113.1, 123.5, 124.4, $130.8,131.2,139.4,142.2,154.5,170.6,177.4,198.4$. IR (ATR): 3362, 2939, 1745, 1643, 1518, 1244, 1204, 891, 839 $\mathrm{cm}^{-1}$. HRMS $\mathrm{m} / z$ : calcd for $\mathrm{C}_{23} \mathrm{H}_{30} \mathrm{NO}_{4}, 384.2175[\mathrm{M}+\mathrm{H}]^{+}$; found, 384.2176 .

13-Propenyl-7-oxoabieta-8,11,13-trien-18-oic Acid (11). Using the general procedure, compound 11 was prepared from 7. Compound 11: yellowish solid. ${ }^{1} \mathrm{H}$ NMR (400 MHz, $\left.\mathrm{CDCl}_{3}\right): \delta 1.28(\mathrm{~s}, 3 \mathrm{H}), 1.36(\mathrm{~s}, 3 \mathrm{H}), 1.66(\mathrm{~m}, 1 \mathrm{H}), 1.83(\mathrm{~m}$, $4 \mathrm{H}), 2.15(\mathrm{~m}, 3 \mathrm{H}), 2.37(\mathrm{~m}, 1 \mathrm{H}), 2.53(\mathrm{~m}, 1 \mathrm{H}), 2.75(\mathrm{~m}, 2 \mathrm{H})$, $5.11(\mathrm{~m}, 1 \mathrm{H}), 5.41(\mathrm{~m}, 1 \mathrm{H}), 7.34(\mathrm{~d}, J=8.3 \mathrm{~Hz}, 1 \mathrm{H}), 7.66$ $(\mathrm{dd}, J=8.3,2.2 \mathrm{~Hz}, 1 \mathrm{H}), 8.09(\mathrm{~d}, J=2.2 \mathrm{~Hz}, 1 \mathrm{H}) .{ }^{13} \mathrm{C}$ NMR $\left(101 \mathrm{MHz} \mathrm{CDCl}_{3}\right): \delta 16.3,18.2,21.8,23.7,36.6,37.1,37.5$, $37.9,43.6,46.5,113.2,123.7,124.5,130.7,131.4,139.5,142.2$, 154.5, 183.0, 198.7. IR (ATR): 3256, 2943, 1722, 1668, 1248, $1165,897,791 \mathrm{~cm}^{-1}$. HRMS $\mathrm{m} / z$ : calcd for $\mathrm{C}_{20} \mathrm{H}_{25} \mathrm{O}_{3}$, 313.1804 $[\mathrm{M}+\mathrm{H}]^{+}$; found, 313.1803.

$\mathrm{N}, \mathrm{N}$-Dimethyl 13-isopropenyl-7-oxoabieta-8,11,13-trien18-amide (12). Using the general procedure, compound 12 was prepared from 8. ${ }^{10}$ Compound 12: white solid. ${ }^{1} \mathrm{H}$ NMR $\left(400 \mathrm{MHz}, \mathrm{CDCl}_{3}\right): \delta 1.28(\mathrm{~s}, 3 \mathrm{H}), 1.44(\mathrm{~s}, 3 \mathrm{H}), 1.62(\mathrm{~m}$, $1 \mathrm{H}), 1.78(\mathrm{~m}, 3 \mathrm{H}), 1.92(\mathrm{~m}, 1 \mathrm{H}), 2.16(\mathrm{~m}, 3 \mathrm{H}), 2.34(\mathrm{~m}, 1 \mathrm{H})$, $2.64(\mathrm{~m}, 2 \mathrm{H}), 2.96(\mathrm{t}, J=8.6 \mathrm{~Hz}, 1 \mathrm{H}), 3.02(\mathrm{~s}, 6 \mathrm{H}), 5.10(\mathrm{~m}$, $1 \mathrm{H}), 5.41(\mathrm{~m}, 1 \mathrm{H}), 7.31(\mathrm{~d}, J=8.3 \mathrm{~Hz}, 1 \mathrm{H}), 7.64(\mathrm{dd}, J=8.3$, $2.2 \mathrm{~Hz}, 1 \mathrm{H}), 8.07(\mathrm{~d}, J=2.2 \mathrm{~Hz}, 1 \mathrm{H}) .{ }^{13} \mathrm{C} \mathrm{NMR}(101 \mathrm{MHz}$, $\left.\mathrm{CDCl}_{3}\right): \delta 18.5,18.7,21.8,24.0,35.6,36.9,37.8,38.4,39.2$, 43.9, 45.8, 112.9, 123.3, 124.2, 130.9, 131.0, 139.2, 142.2, 154.7, 176.9, 199.2. IR (ATR): 2945, 1676, 1618, 1240, 893, $849 \mathrm{~cm}^{-1}$. HRMS $m / z$ : calcd for $\mathrm{C}_{22} \mathrm{H}_{30} \mathrm{NO}_{2}, 340.2277[\mathrm{M}+$ $\mathrm{H}]^{+}$; found, 340.2279 .

13-Propenyl-7-oxoabieta-8,11,13-trien-18-amide (13). Using the general procedure, compound 13 was prepared from 9. ${ }^{10}$ Compound 13: white solid. ${ }^{1} \mathrm{H}$ NMR (400 MHz, $\left.\mathrm{CDCl}_{3}\right): \delta 1.27(\mathrm{~s}, 3 \mathrm{H}), 1.37(\mathrm{~s}, 3 \mathrm{H}), 1.67(\mathrm{~m}, 2 \mathrm{H}), 1.83(\mathrm{~m}$, $3 \mathrm{H}), 2.15(\mathrm{~m}, 3 \mathrm{H}), 2.37(\mathrm{~m}, 1 \mathrm{H}), 2.53(\mathrm{~m}, 1 \mathrm{H}), 2.70(\mathrm{~m}, 2 \mathrm{H})$, $5.11(\mathrm{~m}, 1 \mathrm{H}), 5.41(\mathrm{~m}, 1 \mathrm{H}), 5.65(\mathrm{~s}, 1 \mathrm{H}), 5.79(\mathrm{~s}, 1 \mathrm{H}), 7.33$ $(\mathrm{d}, J=8.3 \mathrm{~Hz}, 1 \mathrm{H}), 7.65(\mathrm{dd}, J=8.3,2.2 \mathrm{~Hz}, 1 \mathrm{H}), 8.06(\mathrm{~d}, J=$ $2.2 \mathrm{~Hz}, 1 \mathrm{H}) .{ }^{13} \mathrm{C} \mathrm{NMR}\left(101 \mathrm{MHz}, \mathrm{CDCl}_{3}\right): \delta 16.9,18.4,21.8$, 23.8, 37.1, 37.1, 37.5, 43.8, 46.5, 113.1, 123.5, 124.4, 130.8, $131.2,139.4,142.2,154.5,179.9,198.4$. IR (ATR): 3354,
3206, 2932, 1680, 1605, 1246, 901, $841 \mathrm{~cm}^{-1}$. HRMS $\mathrm{m} / z$ : calcd for $\mathrm{C}_{20} \mathrm{H}_{26} \mathrm{NO}_{2}, 312.1964[\mathrm{M}+\mathrm{H}]^{+}$; found, 312.1961 .

15-Hydroxy-7-oxoabieta-8,11,13-trien-18-oic Acid (7). A mixture of compound 1 (303 $\mathrm{mg}, 0.879 \mathrm{mmol})$ and $\mathrm{KOH}$ in ethylene glycol/water 10:1 (3.3 mL) was heated to $120{ }^{\circ} \mathrm{C}$. After stirring the solution at $120^{\circ} \mathrm{C}$ for $3.5 \mathrm{~h}$, a $1 \mathrm{M}$ aqueous solution of $\mathrm{HCl}(20 \mathrm{~mL})$ and ethyl acetate $(25 \mathrm{~mL})$ were added. The aqueous phase was extracted with ethyl acetate (2 $\times 25 \mathrm{~mL}$ ), and the combined organic phases were washed with a $1 \mathrm{M}$ aqueous solution of $\mathrm{HCl}(15 \mathrm{~mL})$, water $(15 \mathrm{~mL})$, brine $(15 \mathrm{~mL})$, and dried over anhydrous $\mathrm{Na}_{2} \mathrm{SO} 4$. After removal of the solvent under reduced pressure, the crude product was purified by flash chromatography on silica gel using dichloromethane in methanol $(0 \rightarrow 10 \%)$ as the eluant giving compound 11 (187 mg, 64\%) as a yellowish solid. ${ }^{1} \mathrm{H}$ NMR $\left(400 \mathrm{MHz}_{\mathrm{CDCl}}\right): \delta 1.27(\mathrm{~s}, 3 \mathrm{H}), 1.36(\mathrm{~s}, 3 \mathrm{H}), 1.57(\mathrm{~s}, 3 \mathrm{H})$, $1.58(\mathrm{~s}, 3 \mathrm{H}), 1.66(\mathrm{~m}, 1 \mathrm{H}), 1.83(\mathrm{~m}, 4 \mathrm{H}), 2.38(\mathrm{~d}, J=12.8 \mathrm{~Hz}$, $1 \mathrm{H}), 2.50(\mathrm{~d}, J=15.1 \mathrm{~Hz}, 1 \mathrm{H}), 2.72(\mathrm{~m}, 2 \mathrm{H}), 7.36(\mathrm{~d}, J=8.3$ $\mathrm{Hz}, 1 \mathrm{H}), 7.73(\mathrm{dd}, J=8.3,2.2 \mathrm{~Hz}, 1 \mathrm{H}), 8.06(\mathrm{~d}, J=2.2 \mathrm{~Hz}$, $1 \mathrm{H}) .{ }^{13} \mathrm{C}$ NMR (101 MHz, $\left.\mathrm{CDCl}_{3}\right): \delta 16.3,18.2,23.8,31.7$, 31.8, 36.6, 37.2, 37.4, 37.9, 43.7, 46.5, 72.5, 123.4, 123.8, 130.6, $130.8,147.5,153.9,182.8,198.8$. IR (ATR): $3416,2939,2608$, $1670,1236,1126,752 \mathrm{~cm}^{-1}$. HRMS $m / z$ : calcd for $\mathrm{C}_{20} \mathrm{H}_{27} \mathrm{O}_{4}$, $331.1909[\mathrm{M}+\mathrm{H}]^{+}$; found, 331.1909.

Cedrene (15). Clear colorless liquid. ${ }^{1} \mathrm{H}$ NMR (400 MHz, $\left.\mathrm{CDCl}_{3}\right): \delta 10.84(\mathrm{~d}, J=7.1 \mathrm{~Hz}, 3 \mathrm{H}), 0.95(\mathrm{~s}, 3 \mathrm{H}), 1.02(\mathrm{~s}$, $3 \mathrm{H}), 1.38(\mathrm{~m}, 3 \mathrm{H}), 1.70(\mathrm{~m}, 10 \mathrm{H}), 2.17(\mathrm{~m}, 1 \mathrm{H}), 5.22(\mathrm{~m}$, 1H). $\left.{ }^{13} \mathrm{C} \mathrm{NMR} \mathrm{(101} \mathrm{MHz,} \mathrm{CDCl}_{3}\right): \delta 15.6,24.9,25.0,25.8$, 27.8, 36.2, 39.0, 40.8, 41.6, 48.3, 54.0, 55.0, 59.1, 119.3, 140.7 . All analytical data are in agreement with the literature values. ${ }^{24}$

4-Methyl-2,4-diphenyl-2-pentene (18). ${ }^{24}$ Yellowish liquid. ${ }^{1} \mathrm{H}$ NMR (400 MHz, $\left.\mathrm{CDCl}_{3}\right): \delta 1.22(\mathrm{~s}, 6 \mathrm{H}), 2.83(\mathrm{~s}, 2 \mathrm{H})$, $4.78(\mathrm{~m}, 1 \mathrm{H}), 5.14(\mathrm{~m}, 1 \mathrm{H}), 7.11(\mathrm{~m}, 1 \mathrm{H}), 7.24(\mathrm{~m}, 9 \mathrm{H}) .{ }^{13} \mathrm{C}$ NMR $\left(101 \mathrm{MHz}, \mathrm{CDCl}_{3}\right): \delta 28.9,38.8,49.7,117.0,125.6$, $126.1,126.6,126.9,127.9,128.1,143.6,146.8,149.5$.

13-Propenyl-7-hydroxyabieta-8,11,13-trien-18-oic Acid (27). A mixture of compound $2(0.200 \mathrm{~g}, 0.613 \mathrm{mmol})$ and $\mathrm{KOH}$ in ethylene glycol/water 10:1 $(2.1 \mathrm{~mL})$ was heated to $120{ }^{\circ} \mathrm{C}$. After stirring the solution at $120{ }^{\circ} \mathrm{C}$ for $3 \mathrm{~h}$, a $1 \mathrm{M}$ aqueous solution of $\mathrm{HCl}(7 \mathrm{~mL})$ and ethyl acetate $(20 \mathrm{~mL})$ were added. The aqueous phase was extracted with ethyl acetate $(2 \times 20 \mathrm{~mL})$, and the combined organic phases were washed with a $1 \mathrm{M}$ aqueous solution of $\mathrm{HCl}(10 \mathrm{~mL})$, water $(10 \mathrm{~mL})$, brine $(10 \mathrm{~mL})$, and dried over anhydrous $\mathrm{Na}_{2} \mathrm{SO}_{4}$. After removal of the solvent under reduced pressure, the crude product was purified by flash chromatography on silica gel using ethyl acetate/ethanol $(3: 1)$ in hexane $(0 \rightarrow 100 \%)$ as the eluant giving compound 11 (156 mg, 80\%) as a yellowish solid.

Compound 11 (0.110 g, $0.352 \mathrm{mmol})$ was dissolved in anhydrous methanol $(2 \mathrm{~mL})$ under argon, followed by the addition of sodium borohydride $(107 \mathrm{mg}, 2.82 \mathrm{mmol})$ at $0{ }^{\circ} \mathrm{C}$, and the reaction mixture was stirred at room temperature for $1.5 \mathrm{~h}$. The solvent was carefully evaporated under reduced pressure, and the residue was diluted with ethyl acetate (10 $\mathrm{mL})$ and a $1 \mathrm{M}$ aqueous solution of $\mathrm{HCl}(5 \mathrm{~mL})$ was added. The aqueous phase was extracted with ethyl acetate $(2 \times 10$ $\mathrm{mL})$, and the combined organic phases were washed with a 1 $\mathrm{M}$ aqueous solution of $\mathrm{HCl}(10 \mathrm{~mL})$, water $(10 \mathrm{~mL})$, and brine $(10 \mathrm{~mL})$ and dried over anhydrous $\mathrm{Na}_{2} \mathrm{SO}_{4}$. After removal of the solvent under reduced pressure, the crude product was purified by flash chromatography on silica gel using ethyl acetate/ethanol (3:1) in $n$-heptane $(0 \rightarrow 100 \%)$ as 
the eluant giving compound $27(42 \mathrm{mg}, 37 \%)$ as a white solid. ${ }^{1} \mathrm{H}$ NMR (400 MHz, CD $\left.\mathrm{OD}\right): \delta 1.29(\mathrm{~m}, 6 \mathrm{H}), 1.40(\mathrm{~m}, 1 \mathrm{H})$, $1.77(\mathrm{~m}, 6 \mathrm{H}), 2.12(\mathrm{~m}, 3 \mathrm{H}), 2.22(\mathrm{~m}, 1 \mathrm{H}), 2.34(\mathrm{~m}, 1 \mathrm{H}), 4.75$ $(\mathrm{t}, J=8.8 \mathrm{~Hz}, 1 \mathrm{H}), 5.02(\mathrm{~m}, 1 \mathrm{H}), 5.34(\mathrm{~m}, 1 \mathrm{H}), 7.20(\mathrm{~d}, J=$ $8.3 \mathrm{~Hz}, 1 \mathrm{H}), 7.33$ (ddd, $J=8.3,2.1,0.7 \mathrm{~Hz}, 1 \mathrm{H}), 7.62(\mathrm{dd}, J=$ 2.2, $0.9 \mathrm{~Hz}, 1 \mathrm{H}) .{ }^{13} \mathrm{C}$ NMR $\left(101 \mathrm{MHz}, \mathrm{CD}_{3} \mathrm{OD}\right): \delta 17.0,19.5$, 22.0, 25.7, 33.3, 37.8, 38.9, 39.3, 44.9, 48.2, 71.2, 111.9, 125.1, 125.6, 125.7, 139.1, 139.9, 144.6, 149.8, 182.1. IR (ATR): 3296, 2930, 2619, 1691, 1246, 999, 885, $825 \mathrm{~cm}^{-1}$. HRMS m/ $z$ : calcd for $\mathrm{C}_{20} \mathrm{H}_{25} \mathrm{O}_{3} 313.1804[\mathrm{M}-\mathrm{H}]^{-}$; found, 313.1805 .

\section{ASSOCIATED CONTENT}

\section{S Supporting Information}

The Supporting Information is available free of charge on the ACS Publications website at DOI: 10.1021/acsomega.8b01401.

NMR spectra for compounds $2-4,7,10-13,15,18,23$, 24, and 27 (PDF)

\section{AUTHOR INFORMATION}

\section{Corresponding Author}

*E-mail: vania.moreira@strath.ac.uk.

\section{ORCID}

Jari Yli-Kauhaluoma: 0000-0003-0370-7653

Vânia M. Moreira: 0000-0001-6169-5035

\section{Notes}

The authors declare no competing financial interest.

\section{ACKNOWLEDGMENTS}

L.E.K., V.M.M., and J.Y.-K. acknowledge the University of Helsinki Research Foundation and the Academy of Finland (Projects 264020 and 265481) for the financial support.

\section{ADDITIONAL NOTES}

${ }^{a_{\text {The }}}$ configuration of dimeric compound $\mathbf{5}$ was assigned to $E$ based on the NOESY correlation between the $17^{\prime}-\mathrm{H}$ signal of the double bond at $6.14 \mathrm{ppm}$ and the methyl group protons signals at $1.51 \mathrm{pm}$ (Table 1$)$.

$b_{\text {The }} \alpha$-orientation of H-7 was assigned by the presence of a NOESY-correlation of $\mathrm{H}-5 / \mathrm{H}-7$ and the broad triplet at 4.75 $(\mathrm{t}, J=8.8 \mathrm{~Hz}$ ), consistent with a previous study (see ref 12 ).

\section{REFERENCES}

(1) (a) March, J. A. Advanced Organic Chemistry: Reactions, Mechanisms and Structures, 3rd ed.; McGraw-Hill: New York, 1985. (b) Larock, R. C. Comprehensive Organic Transformations; VHC Publisher, 1989. (c) Buehler, C. A.; Pearson, D. E. Survey of Organic Syntheses; Wiley Interscience New York, 1970; Vol. 2.

(2) (a) Molnar, A.; Bartok, M. Fine Chemicals through Heterogeneous Catalysis; Wiley-VCH: Weinheim, 2001. (b) Kunkes, E. L.; Simonetti, D. A.; West, R. M.; Serrano-Ruiz, J. C.; Gartner, C. A.; Dumesic, J. A. Catalytic conversion of biomass to monofunctional hydrocarbons and targeted liquid-fuel classes. Science 2008, 322, 417-421.

(3) (a) Kostestkyy, P.; Yu, J.; Gorte, R. J.; Mpourmpakis, G. Structure-activity relationships on metal-oxides: alcohol dehydration. Catal. Sci. Technol. 2014, 4, 3861-3869. (b) Roy, S.; Mpourmpakis, G.; Hong, D.-Y.; Vlachos, D. G.; Bhan, A.; Gorte, R. J. Mechanistic Study of Alcohol Dehydration on $\gamma-\mathrm{Al}_{2} \mathrm{O}_{3}$. ACS Catal. 2012, 2, 18461853. (c) Kostetskyy, P.; Mpourmpakis, G. Structure-activity relationships in the production of olefins from alcohols and ethers: a first-principles theoretical study. Catal. Sci. Technol. 2015, 5, 45474555.
(4) (a) Austin, N.; Kostetskyy, P.; Mpourmpakis, G. Design of highly selective ethanol dehydration nanocatalysts for ethylene production. Nanoscale 2018, 10, 4004-4009. (b) Song, Y.; Xu, S.; Ling, F.; Tian, P.; Ye, T.; Yu, D.; Chu, X.; Lin, Y.; Yang, X.; Tang, J. Atomic layer deposition of aluminium on anatase: A solid acid catalyst with remarkable performances for alcohol dehydration. Catal. Commun. 2017, 99, 34-38. (c) Liu, C.; Pan, B.; Gu, Y. Lewis baseassisted Lewis acid-catalyzed selective alkene formation via alcohol dehydration and synthesis of 2-cinnamyl-1,3-dicarbonyl compounds from 2-aryl-3,4-dihydropyrans. Chin. J. Catal. 2016, 37, 979-986. (d) Kostetskyy, P.; Zervoudis, N. A.; Mpourmpakis, G. Carboranes: the strongest Brønsted acids in alcohol dehydration. Catal. Sci. Technol. 2017, 7, 2001-2011.

(5) (a) Hua, R. Recent advances in bismuth-catalyzed organic synthesis. Curr. Org. Synth. 2008, 5, 1-27. (b) Ollevier, T. New trends in bismuth-catalyzed synthetic transformations. Org. Biomol. Chem. 2013, 11, 2740-2755. (c) Leonard, N. M.; Wieland, L. C.; Mohan, R. S. Applications of bismuth(III) compounds in organic synthesis. Tetrahedron 2002, 58, 8373-8397. (d) Suzuki, H.; Komatsu, N.; Ogawa, T.; Murafuji, T.; Ikegami, T.; Matano, Y. Organobismuth Chemistry; Elsevier Science, 2001. (e) GaspardIloughmane, T.; Le Roux, C. Acid Catalysis in Modern Organic Synthesis; Yamamoto, H., Ishihara, K., Eds.; John Wiley \& Sons, 2008; pp 551-588. (f) Yadav, J. S.; Antony, A.; Reddy Subba, B. V. BismuthMediated Organic Reactions; Ollevier, T., Ed.; Springer-Verlag Berlin Heidelberg, 2011; pp 229-269. (g) Bothwell, J. M.; Krabbe, S. W.; Mohan, R. S. Applications of bismuth(III) compounds in organic synthesis. Chem. Soc. Rev. 2011, 40, 4649-4707. (h) Ondet, P.; Lemière, G.; Duñach, E. Cyclisations catalysed by bismuth(III) triflate. Eur. J. Org. Chem. 2017, 761-780.

(6) (a) Salvador, J. A. R.; Figueiredo, S. A. C.; Pinto, R. M. A.; Silvestre, S. M. Bismuth compounds in medicinal chemistry. Future Med. Chem. 2012, 4, 1495-1523. (b) Salvador, J. A. R.; Silvestre, S. M.; Pinto, R. M. A. Bismuth(III) reagents in steroid and terpene chemistry. Molecules 2011, 16, 2884-2913. (c) Evans, P. A.; Cui, J.; Gharpure, S. J. Stereoselective Construction of cis-2,6-Disubstituted Tetrahydropyransviathe Reductive Etherification of $\delta$-Trialkylsilyloxy Substituted Ketones: Total Synthesis of (-)-Centrolobine. Org. Lett. 2003, 5, 3883-3885. (d) Evans, P. A.; Cui, J.; Gharpure, S. J.; Polosukhin, A.; Zhang, H.-R. Enantioselective Total Synthesis of the Potent Antitumor Agent (-)-Mucocin Using a Temporary SiliconTethered Ring-Closing Metathesis Cross-Coupling Reaction. J. Am. Chem. Soc. 2003, 125, 14702-14703. (e) Nicolaou, K. C.; Carenzi, G. E. A.; Jeso, V. Construction of highly functionalized medium-sized rings: synthesis of hyperforin and perforatumone model systems. Angew. Chem., Int. Ed. 2005, 44, 3895-3899. (f) Salvador, J. A. R.; Moreira, V. M.; Pinto, R. M. A.; Leal, A. S.; Le Roux, C. Bismuth(III) Triflate-Based Catalytic Direct Opening of Oleanolic Hydroxy- $\gamma$ lactones to Afford 12-Oxo-28-carboxylic Acids. Adv. Synth. Catal. 2011, 353, 2637-2642. (g) Wipf, P.; Hopkins, T. D. Total synthesis and structure validation of (+)-bistramide C. Chem. Commun. 2005, $3421-3423$

(7) Gaspard-Iloughmane, H.; Le Roux, C. Bismuth(III) triflate in organic synthesis. Eur. J. Org. Chem. 2004, 2517-2532.

(8) Keramane, E. M.; Boyer, B.; Roque, J.-P. Reactivity of bismuth(III) halides towards alcohols. A tentative to mechanistic investigation. Tetrahedron 2001, 57, 1909-1916.

(9) Dorta, R. L.; Suárez, E.; Betancor, C. Triphenylbismuth dibromide-iodine: an efficient reagent for the dehydration of alcohols. Tetrahedron Lett. 1994, 35, 5035-5038.

(10) Kolsi, L. E.; Krogerus, S.; Brito, V.; Rüffer, T.; Lang, H.; YliKauhaluoma, J.; Silvestre, S. M.; Moreira, V. M. Regioselective benzylic oxidation of aromatic abietanes: application to the semisynthesis of the naturally occurring Picealactones A, B and C. ChemistrySelect 2017, 2, 7008-7012.

(11) Zhao, Y.-J.; Loh, T.-P. Asymmetric total synthesis of antiochic acid. Org. Lett. 2008, 10, 2143-2145. 
(12) Yang, N.-Y.; Liu, L.; Tao, W.-W.; Duan, J.-A.; Tian, L.-J. Diterpenoids from Pinus massoniana resin and their cytotoxicity against A431 and A549 cells. Phytochemistry 2010, 71, 1528-1533.

(13) Yang, L.; Qiao, L.; Ji, C.; Xie, D.; Gong, N.-B.; Lu, Y.; Zhang, J.; Dai, J.; Guo, S. Antidepressant abietane diterpenoids from Chinese Eaglewood. J. Nat. Prod. 2013, 76, 216-222.

(14) Gao, J.-B.; Yang, S.-J.; Yan, Z.-R.; Zhang, X.-J.; Pu, D.-B.; Wang, L.-X.; Li, X.-L.; Zhang, R.-H.; Xiao, W.-L. Isolation, Characterization, and Structure-Activity Relationship Analysis of Abietane Diterpenoids from Callicarpa bodinieri as Spleen Tyrosine Kinase Inhibitors. J. Nat. Prod. 2018, 81, 998-1006.

(15) Shao, L. P.; Gäfvert, E.; Nilsson, U.; Karlberg, A.-T.; Nilsson, J. L. G. 15-hydroperoxydehydroabietic acid-a contact allergen in colophony from Pinus species. Phytochemistry 1995, 38, 853-857.

(16) Li, W.-S.; McChesney, J. D. Preparation of potential antiinflammatory agents from dehydroabietic acid. J. Pharm. Sci. 1992, 81, 646-651.

(17) Norin, T.; Winell, B.; Enzell, C. R.; Nilsson, J. L. G.; Svensson, S. Extractives from the Bark of Common Spruce, Picea abies L. Karst. Acta Chem. Scand. 1972, 26, 2289-2296.

(18) Wabnitz, T. C.; Yu, J.-Q.; Spencer, J. B. Evidence that protons can be the active catalysts in Lewis acid mediated hetero-Michael addition reactions. Chem. Eur.-J. 2004, 10, 484-493.

(19) Dai, J.; Wu, J.; Zhao, G.; Dai, W.-M. In(OTf) ${ }_{3}$-Catalyzed Highly Chemo- and Regioselective Head-to-Tail Heterodimerization of Vinylarenes with 1,1-Diarylethenes. Chem. Eur.-J. 2011, 17, $8290-8293$.

(20) Liu, M.; Zhang, J.; Zhou, H.; Yang, H.; Xia, C.; Jiang, G. Efficient hydroarylation and hydroalkenylation of vinylarenes by Brønsted acid catalysis. RSC Adv. 2016, 6, 76780-76784.

(21) Rosen, M. J. Studies on the dimerization of styrene in aqueous sulfuric acid. J. Org. Chem. 1953, 18, 1701-1705.

(22) Fehn, S.; Schwarz, S.; Kempe, R. Regioselective heterodimerization of styrenes with diarylethene and vinylnaphthalene by a catalyst system consisting of simple acid and a ketone. ChemistrySelect 2017, 2, 3289-3292.

(23) Howard, F.; Sawadjoon, S.; Samec, J. S. M. A chemoselective route to either 4-methyl-2,4-diphenyl-2-pentene or 1,1,3-trimethyl-3phenylindane from 2-phenylpropan-2-ol mediated by $\mathrm{BiBr}_{3}$ : a mechanistic study. Tetrahedron Lett. 2010, 51, 4208-4210.

(24) Schmalz, H.-G.; Westphal, J.; Schumacher, C. E. The wender cedrene synthesis revisited: a catalytic enantioselective entry to the chiral key intermediate. Synthesis 2017, 218-224. 